Svetlana Strilets

ORCID: 0000-0003-2854-9188

Marina Grenok

Czernihowski Narodowy Uniwersytet Pedagogiczny im. T. Szewczenki

Ukraina

\title{
Дидактическая сказка в подготовке будущих учителей начальной школы
}

\section{Didactic fairytales in the training of primary school teachers}

https://doi.org/10.34739/sn.2019.19.11

\begin{abstract}
Аннотация: В статье рассмотрена проблема подготовки будущих учителей начальной школы к созданию дидактических сказок в условиях новой украинской школы. Акцентируется внимание на том, что подготовленный учитель может создавать дидактические сказки, которые заинтересуют учащихся и будут способствовать эффективному усвоению знаний. Предложен один из вариантов этапов создания дидактической сказки, представлены оптимальные методы и приемы создания дидактической сказки, адаптированые для подготовки учителей начальных классов. Осуществлена экспериментальная проверка эффективности подготовки будущих учителей начальных классов к созданию дидактических сказок.

Ключевые слова: реформация образовательного процесса начальной школы, инновационные и интерактивные методы, творчество учителя начальных классов, приемы создания сказок, дидактическая сказка
\end{abstract}

Abstract: The article deals with training future primary school teachers to use didactic fairy tales. A special emphasis is placed on the fact that a trained teacher can create didactic fairytales that interest students and contribute to their effective mastering of knowledge. One of the variants of stages in making a didactic fairytale has been offered, optimal methods and ways of its making have been presented and adapted for the primary school teacher's training. The experimental testing of future primary school teachers' training effectiveness for making didactic fairytales has been carried out.

Keywords: reforming primary school educational process, innovative and interactive methods, primary school teachers' creativity, ways of making fairytales, didactic fairytales

Постановка проблемы. Постоянное стремление человечества к модернизации образования, улучшение образовательного процесса обусловили возникновение множества инноваций, повлекшие в свою 
очередь его реформирование. На современном этапе развития образования обращается большое внимание на важность подготовки креативного учителя начальной школы, а также на создание условий для улучшения образовательного процесса учащихся. Мы считаем, что образовательный процесс в начальной школе необходимо максимально приблизить к детскому пониманию, восприятию, важно создать естественные условия в соответствии с потребностями, интересами и желаниями учащихся. Одним из эффективных методов решения этой проблемы является использование дидактических сказок на разных уроках в начальной школе. Именно дидактическая сказка - неотьемлемая составляющая детской жизни, через нее ученики получают практические знания, познают мир, учатся правильно действовать в различных ситуациях. Кроме этого, ученикам нравится слушать сказки, их анализировать, обсуждать, разыгрывать и тому подобное. Итак, актуальным становится вопрос подготовки учителей начальных классов к созданию сказок. Такой учитель сможет писать собственные дидактические сказки, адаптировать их к потребностям соответствующего класса, разрабатывать авторские программы с их использованием.

Анализ последних исследований и публикаций. По-прежнему актуальны вопросы инноваций в высшем педагогическом образовании (О. Антонова, О. Дубасенюк, С. Стрилец, М. Козловец, П. Саух и др.). Достаточно полно изучены различные теоретические аспекты сказки (И. Безпечный, А. Галич, Л . Дунаевская, М. Лановик, М. Моклица, Н. Ференц и др.), оцениваются возможности дидактической сказки в начальной школе (О. Баширова, И. Гановская, В. Чернишук и др.), рассматривается роль сказки в воспитании и обучении (Л. Залиток, М. Кальчук, В. Любичева, В. Сухомлинский и др.), обращается внимание на повышение мотивации у учащихся с помощью сказки (Т. Алексейчик), на развитие психических процессов, творческих способностей с помощью сказки (О. Барнич, А. Лизун, О. Сергеенкова и др.), изучается сказкотерапия (М. Бережная, О. Бредихина, О. Логинова, Д. Соколов, Л. Соловьева, Л. Хижняк и др.). Часто можно встретить авторские сказки, которые используются на уроках в начальной школе (В.Бутрим, М. Гренок, М. Ефименко, А. Колиснык, М. Квилинская и др.). Несколько меньше освещена проблема создания сказок, приемов фантазирования (В. Пропп, Д.Родари, М.Туров и др.). Для большинства работ свойственно акцентирование внимания на происхождении сказки, ее видов, функций, 
на особенности построения, на воспитательном воздействии на ребенка. Не в полной мере в педагогике исследована тема дидактической сказки как метода мотивации учащихся, изучения и закрепления учебного материала. Пока не хватает работ, в которых бы освещалась тема подготовки будущих учителей начальной школы к созданию дидактических сказок, что составляет новизну нашего исследования.

Цель статьи - поделиться опытом модернизации содержания образования путем подготовки будущих учителей начальной школы к созданию дидактических сказок.

Изложение основного материала. Учеными доказано, что при наличии интереса, положительных эмоций, знания усваиваются основательно, прочно. Результаты анализа факторов развития познавательного интереса показали, что для развития познавательного интереса и мотивации учения эффективным является использование дидактических сказок. Дидактическая сказка - это учебный материал, представленный ученикам в форме сказки, служит средством стимулирования любознательности и интереса к познанию, к усвоению новых знаний, развитию воображения, внимания, памяти и мышления. Дидактические сказки создаются педагогами для подачи учебного материала, они могут раскрывать сущность и важность определенных знаний. Это дает основание утверждать, что дидактические сказки являются эффективным средством развития познавательного интереса младших школьников при условии соблюдения выявленных методических положений. Их создание и использование на уроках является научно обоснованным и педагогически целесообразным. Дидактическая сказка стимулирует волевые действия ребенка, помогает преодолевать трудности в обучении путем удовлетворения своих эмоциональных потребностей. Обучающая сказка способствует успешному прохождению психических процессов, лучшему усвоению учебного материала [Гановська].

На основе изученной литературы, а также после проведения экспериментального исследования выделили основные сферы, в которых учителю нужна профессиональная подготовка: 1) изучение возрастных особенностей детей младшего школьного возраста, особенности протекания психических процессов в этом возрасте; 2) исследование тем, волнующих детей вообще в этом возрасте, а также интересы конкретной группы детей (тот класс, в котором учитель работает); 3) ознакомление с различными авторскими дидактическими сказками; 4) умение выражать 
собственное мнение грамотно; 5) ознакомление с особенностями влияния сказки на ребенка; 6) исследовать структуру, функции, виды сказок, этапы их написания; 7) изучить приемы и методы создания дидактической сказки; 8) тренироваться в создании дидактических сказок.

Во время обработки литературы [Справочник; Литературная мастерская, 2013] и проведения формирующего эксперимента, когда студенты создавали сказки, выделили основные этапы составления дидактической сказки: 1) выяснение общей цели написания сказки; 2) определение цели и темы урока; 3) выяснение конкретной цели написания сказки; 4) выбор методов и приемов создания дидактической сказки; 5) написание синопсиса (краткого содержания); 6) продумать сюжет сказки и персонажей; 7) написать краткий план сказки; 8) продумать описание героев, локаций, сцен; 9) подробно описать события, продумать логические переходы от одного эпизода событий к другому; 10) проверить соответствие сказки задуманной цели ее написания; 11) редактировать дидактическую сказку.

Необходимо помнить, что алгоритм написания сказки у каждого автора может отличаться, но выше приведенный поможет учителям начальных классов начать свое писательское мастерство.

Следующей важной составляющей подготовки учителя является ознакомление с приемами написания сказок, которые дают возможность быстро составить интересную $и$ необычную сказку. Проработав существующую научную литературу, мы выделили методы создания сказок и адаптировали некоторые из них. Каждый метод по-своему уникален и имеет свои особенности. В зависимости от цели написания дидактической сказки, могут использоваться различные приемы и методы по усмотрению автора.

Первый метод - структурирование сказок с помощью карточек Проппа, то есть набора карточек с символами и объяснением, в которых представлены функции сказки, они как бы являются условным планом развития событий. Их можно раскладывать и комбинировать в задуманном порядке, вписывая свои идеи. Такие карты удобны и наиболее продуктивны в процессе написания дидактической сказки. Этот метод написания сказки предложил Владимир Яковлевич Пропп в работах «Морфология сказки», «Трансформация волшебных сказок», «Исторические корни волшебной сказки». Пропп построил теорию, 
согласно которой структура сказки повторяет структуру древнего ритуала [Пропп, 1986].

Второй метод - «Стори Мепс» (StoryMaps) - компьютерная программа, позволяющая произвольно спланировать свою сказку. Приложение работает на Microsoft Windows, Mac OS X или Linux. В приложении использованы иллюстрации дизайнера Раймонда Юэна (англ. Raymond Yuen). В основу сюжетных карт положен функциональный подход Проппа к исследованию традиционных сказок и морфологии сказки [Алексаненкова].

Третий метод - составление сказки с помощью приемов Джанни Родари. Знаменитый итальянский детский писатель Джанни Родари написал книгу «Грамматика фантазии», где изложил несколько десятков приемов, помогающих придумывать разные истории. Коротко рассмотрим некоторые из рекомендованых Родари приемов и методов [Родари, 1990; Туров, 2003]:

1. Сказка «на новый лад» - вспомнить знакомую сказку и переделать ее на новый лад, добавляя необходимый учебный материал. K известным народным сказкам можно добавить элементы современной жизни (например, современную одежду, технические устройства).

2. «А что было потом?» - продолжение известной сказки (например, Золушка готовит еду для своих детей, ей нужно собрать определенное количество яблок на клубнику для пирога, но она не умеет считать и т.д.).

3. «Сказки наизнанку» - попробуйте нафантазировать разные истории, где роли героев, их характеры меняются местами. Например, как изменилась бы сказка, если бы волк оказался хорошим героем, а Красная Шапочка, наоборот, плохая.

4. «Сказочный салат» - сочетание известных героев из сказок или сказочных сюжетов.

5. «Фантастическое исключение». Попробуйте мысленно убрать из сказки то, что существует на свете. Например, «Однажды Зебра проснулась без черных полосок на шерсти ...», «Проснулась утром Маша, а солнца на небе нет».

6. Составление гипотез - «Что было бы, если бы мы зашли в лифт, а исходя из него, оказались в Стране геометрических фигур...», 
«Что было бы, если бы микробы начали разговаривать», «Что было бы, если бы город Чернигов был окружен водой.».

7. «Случайный префикс» - придумывание случайного префикса к существительному (например, мини-небоскреб).

8. Игра «Слепые ответы» - группа людей пишет ответы на вопросы по очереди, не подглядывая ответы тех, кто писал впереди (Кто это был? Где находился? Что сделал? Что сказал? Что сказали люди? Чем закончилось?). В конце получается В большинстве случаев юмористическая история, которую можно взять как идею к созданию сказки.

9. «Рисунок в несколько рук» - один начинает изображать рисунок, другой - продолжает, но не зная, что рисовал первый участник и тому подобное. Таким образом можно изобразить несуществующего персонажа.

10. «Фантастический анализ» - это условное «расчленение сказочного героя» с целью выяснения тех черт и признаков, присущих конкретному герою (например, Пиноккио - дерево, ключик, длинный нос) и в дальнейшем эти признаки или черты можно «обыграть» (например, Пиноккио сделан не из дерева, а из железа или бумаги).

11. «Стеклянный человек» - из характерных особенностей героя выводим логические происшествия (например, стеклянный человек прозрачный, поэтому можно читать его мысли; хрупкий, поэтому все улицы устланы подушками).

12. «Оживление предметов» (живые конфеты, учебники, камни и т.д.).

13. Небольшой рассказ можно придумать, оттолкнувшись от ошибки. Например, девочка всегда надевает перчатки на ноги, или оживить известную метафору (например, время остановилось), или переместить обычного героя в необычную для него обстановку (волка в море, рыбку в лес и т.д.).

14. «Соотношение - противопоставление» - подбор сказочному герою несвойственных ему признаков (например, большая муха и малый слон, большой муравей и малый человек).

15. «Замедление-ускорение»-метод управления временем.

Таким образом, можно сказать, что методы Джанни Родари чрезвычайно полезны при написании дидактической сказки. Они облегчают придумывание сказочного очарования и необычности. 
Следующий метод «нарезок» или метод разрезок (также называемый «cut-up method» или «cut-up technique») - это зависимая от случая литературная техника или жанр, в котором текст в случайном порядке разрезается и перемешивается для создания нового произведения. Суть метода: берется книга, из нее вырезают небольшие фрагменты текста, после чего из этих кусочков составляют новое произведение с кардинально другим содержанием. Изобретение метода нарезок приписывают поэту-дадаисту из Франции Трисатну Тцары. Эту технику усовершенствовал Уильям Берроуз. Он использовал ее при написании нескольких книг [Любавина, 2013; Вікіпедія].

Следующим методом является настольные игры - метод составления дидактической сказки с помощью игровых кубиков, карточек и тому подобное. Существует достаточное количество различных кубиков игр для придумывания историй. Все они очень похожи, в основном, отличаются изображениями. Известными и популярными являются именно такие игры: «Создаем сказки», «Рориз Стори Кубс» (англ. «Rory's Story Cubes»), Стори кубс ( «Story Cubes»).

Кроме настольных игр, существуют также и телефонные игры метод создания дидактических сказок с помощью мобильного приложения «Рориз Стори Кубс» (Rory's Story Cubes), «Стори Дайс» (Story Dice), «Стори Дайс - Сторителинг» (Story Dice - Story telling ) и др. Такие игры могут иметь большее количество изображений, чем реальные кубики, потому влияет на возможность создавать большое количество сказок на различную тематику.

Следующий метод - Уолта Диснея «Три стулья» - методика креативности, проводимой в форме ролевой игры, в которой участники рассматривают поставленную задачу с трех точек зрения: творческой, реалистической и критической. Анализируя этот метод, убедились, что его стоит использовать при создании дидактических сказок, ведь перевоплощение в сказочного героя, представление себя на его месте позволит реалистично описать чувства, внутренние переживания, намерения героев. Коротко рассмотрим суть метода, состоит из трех «взглядов» [Сайт Голубевой Марины; HR - Portal, 2015].

Первый взгляд - взгляд мечтателя, который генерирует различные, нередко совершенно фантастические идеи. Мечтатель не имеет никаких ограничений, для него самое главное, что его воображение способно отрываться от реальности. Второй взгляд - взгляд 
реалиста. Он точно знает, что нужно сделать и всегда может выбрать из многообразия предложений те, которые возможно реализовать в условиях данной реальности. Оценивая идеи мечтателя, он пытается каждую из них «примерить» к решению проблемы. Третий взгляд взгляд Критика, который предупреждает возможные трудности и ошибки, связанные с воплощением в жизнь идей мечтателя. Он должен предусмотреть все проблемы на пути реализации решений, увидеть все опасности, почувствовать все угрозы. Для облегчения перехода от одной позиции к другой Уолт Дисней предложил использовать три стула, стоящих в разных углах комнаты (или в разных комнатах). Посидев на разных стульях, можно описать более полную картину внутренних чувств, мыслей, намерений героя [Сайт Голубевой Марины; HR - Portal, 2015].

Рассмотрим также методы гештальтпсихологии. Гештальтпсихология (от нем. gestalt - образ, форма, структура) - это общее психологическое направление, связанное с попытками объяснения, прежде всего восприятия, мышления личности. Гештальтпсихология имеет свои особенности, инструменты, базируется на определенных концепциях, принципах и тому подобное. В работе обращаем внимание не на само направление гештальтпсихологии, а на адаптированное использование его упражнений, игр, экспериментов. Изучая упражнения, используемые в гештальттерапии, мы заметили, что они могут быть полезными и для писателей, поскольку могут помочь описать более точно и реалистично внутренние переживания героев, мысли, намерения и ожидания [Фаликман, 2016]. Для примера рассмотрим некоторые упражнения [Осика, 2011; Романин]:

1. Упражнение «Горячий стул» (столкновение противоположностей). Члены группы садятся на стулья по кругу. Один из членов по собственному желанию садится посредине круга на так называемый «горячий стул» и начинает откровенно говорить о своих проблемах и отвечать на вопросы других участников группы. С помощью такого метода можно создать групповую дидактическую сказку. На «горячий стул» садится человек, который в своей жизни пережил частично похожую ситуацию, как и герой сказки. Такая интерактивная работа способствует не только правильному описанию внутреннего состояния героя, но и возникновению различных творческих идей. 
2. Упражнение «Две роли». Напротив участника, который сидит на «горячем стуле», ставиться пустой стул; на нем якобы располагается условный человек, с которым в участника возник конфликт. Участник начинает играть две роли. Со стула он обращается от своего имени к воображаемому партнеру, а пересаживаясь на его стул, пытается максимально понять состояние другого и отвечать за него самому себе. В процессе такого объяснения он невольно начинает смотреть на конфликт глазами с другой стороны - лучше понимать другого.

Таким образом, принимая адаптированные методы гештальтпсихологии, можно использовать их для других целей - для правильного описания чувств героев дидактической сказки, их намерений, мыслей и переживаний. Такие методы более эффективно использовать во время группового создания сказки.

Следующий метод - использование интеллект-карт («Mind Maps»), их создатель - британский психолог Тони Бьюзен. Также часто встречаются синонимичные переводы: карта (мапа) ассоциаций; ментальная карта; дерево ассоциаций; карта ума; карта мнений; карта памяти. При создании дидактических сказок возможно записывать мысли, идеи в виде интеллект-карты, что активизирует познавательную деятельность автора, упрощает понимание и классификацию определенного материала, дает возможность четко понимать логические связи, классифицировать информацию, графически изобразить развитие событий, помогает систематизировать и структурировать линейный текст [Вікіпедія].

Важными при создании дидактических сказок являются методы ТРИЗ (теория решения изобретательских задач) - методика творчества в области изобретательства, разработанная Генрихом Альтшуллером. Рассмотрим методы, которые целесообразно использовать при придумывании сказок [Вас вітає садочок Умка, 2015].

Метод контрольных вопросов (МКЗ) является усовершенствованным вариантом метода проб и ошибок, а также одним из методов активизации творческого мышления. Рассмотрит некоторые приемы [Вас вітає садочок Умка, 2015]: 1) максимизация, миниатюризация уменьшение или увеличение объекта по частям: пчела с длиннымдлинным жалом; 2) универсализация - придумывание несвойственных объекту частей, признаков, элементов, последовательности: пчелы без меда; вишни без косточек; школа в виде подводного корабля; 
3) предоставление объекту необычного вида: домик превращается в госпиталь для животных или в отель для мурашек.

Метод фокальных объектов (МФО) - метод, ориентированный на поиск идей в неожиданных направлениях, позволяет отслеживать динамику внешней среды зачастую противоположным взглядом, развивает диалектику мышления. Автором методики является Ч. Вайтинг. Суть метода заключается в переносе свойств одного предмета на другой. Фокальным называют объекты, находящиеся в фокусе, в центре внимания [Вас вітає садочок Умка, 2015]. Рассмотрим метод на примере. Возьмем слово в фокусе - школу. Слова-помощники: 1) персик - вкусный, оранжевый, пахнет, с косточкой; 2) корабль - в воде, перемещается, является капитаном, имеет парус. Теперь соединяем описание, и у нас получается такая школа: в воде, перемещается, оранжевая.

Метод моделирования маленькими человечками (метод ММЧ). Суть метода заключается в том, что нужно представить, что все вещества, предметы, объекты, явления состоят из множества живых, мыслящих маленьких человечков. Они могут передвигаться или выполнять какие-то действия. Благодаря таким человечкам можно рассказать о трех состояниях воды: твердая, редкая, газообразная. Твердое состояние могут отображать человечки, которые крепко держатся друг за друга; редкое человечки не держатся за руки, но стоят рядом; газообразное - человечки живут независимо друг от друга: кто прыгает, кто-то бегает [Дичковская, 2004]. Моделирование маленькими человечками может создаваться в форме дидактической сказки, что облегчит обучение учащихся начальной школы. Такие образы, аналогии и наглядное иллюстрирование сделает образовательный процесс более интересным, более доступным и эффективным.

Во время проведения экспериментального исследования студенты отметили, что использование перечисленных методов и приемов значительно облегчает процесс создания дидактической сказки, поскольку влияет на скорость и производительность фантазии, образного мышления, творческого воображения. Таким образом, чем лучше учитель подготовлен в теоретической составляющей, тем больше у него возможностей создать дидактическую сказку, которая улучшила бы образовательный процесс учащихся начальной школы.

С целью проверки приведенных теоретических положений было проведено экспериментальное исследование подготовки будущих 
учителей начальной школы к созданию дидактических сказок. Исследование проводилось в Национальном университете «Черниговский коллегиум» имени Т.Г. Шевченко на факультете начального обучения.

Констатирующий этап проводился в мае 2017 года и предусматривал применение таких методов исследования: 1) анкетирование 115 студентов II, III, IV курсов с целью выяснения актуальности проблемы; 2) индивидуальный избирательный и групповой опрос студентов с целью уточнения и дополнения личных данных; 3) индивидуальные анонимные беседы с учителями начальных классов и преподавателями.

Для оценки полученных результатов нами были выбраны следующие критерии: а) мотивационный; б) информационный; в) деятельный; г) языковой; д) творческий. Было определено три уровня готовности учителей начальных классов к творческой деятельности в сфере составления дидактических сказок: высокий, средний и начальный. По названным критериям получены следующие результаты: высокий уровень готовности к созданию дидактических сказок имеют 4\% студентов, средний уровень - 56\% студентов и начальный - $40 \%$ студентов (рис. 1).

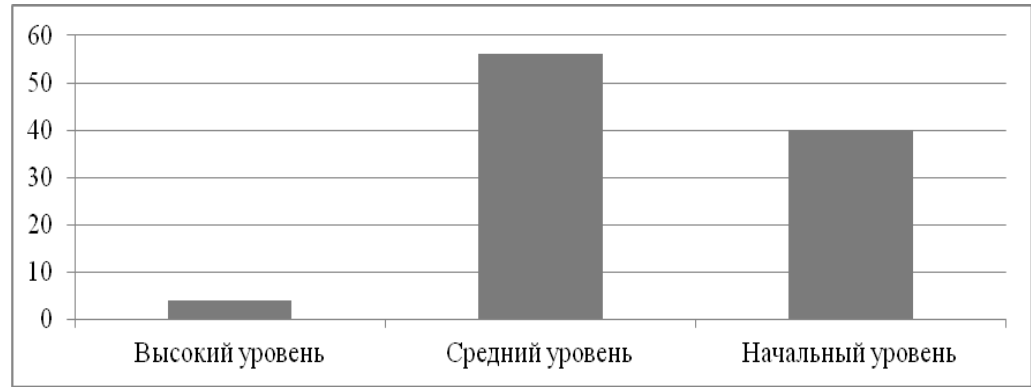

Рис. 1. Результаты констатирующего исследования

В результате исследования установлено, что подготовка будущих учителей начальных классов к созданию дидактических сказок является актуальной проблемой и требует дальнейшего развития. В процессе анализа психолого-педагогической и научно-методической литературы, проведениея педагогического эксперимента сформулированы следующие основные дидактические условия подготовки будущих 
педагогов в этой сфере: 1) стимулирование мотивации развития литературных способностей студентов путем обогащения их эмоционально-чувственного и коммуникативного опыта; 2) знакомство студентов с теоретическими основами дидактической сказки (происхождение, виды, функции, структура, классификации и т.д.); 3) знакомство с методикой создания дидактической сказки (структура, цель, этапы, методы создания и т.д.); 4) ознакомление студентов с условиями успешного использования дидактических сказок на уроках в начальной школе; 5) анализ студентами примеров дидактических сказок и тренировка для создания собственных; 6) создание развивающие-творческой среды, в рамках которой студенты могут взаимодействовать друг с другом, создавать и презентовать свои сказки. С целью проверки указанных дидактических условий был разработан курс тренингов «Учимся создавать дидактические сказки», состоящий из шести занятий, где студенты изучали структуру, этапы, методы, приемы создания сказки.

Тема первого занятия: «Теоретические основы дидактической сказки». Цель: познакомить и расширить знания студентов о происхождении сказки, ее структуре, видах, функциях, классификации; развивать педагогические способности студентов; способствовать воспитанию деловых качеств будущих учителей. Второе занятие было посвящено такой теме: «Теоретические основы создания дидактической сказки». Цель: ознакомить студентов с целью и этапами создания дидактической сказки; развивать педагогические способности студентов; способствовать воспитанию деловых качеств будущих учителей. Третья, четвертая и пятая встречи были посвящены такой теме: «Методы и приемы создания дидактических сказок». Цель: ознакомить студентов с приемами создания дидактических сказок по Дж. Родари, с карточками В. Проппа, приемами фантазирования в ТРИЗ; научить студентов использовать предложенные приемы для создания авторских дидактических сказок; развивать педагогические, литературные способности студентов; способствовать воспитанию деловых качеств будущих учителей. Тема последней встречи «Презентация авторских дидактических сказок для начальной школы». Цель: презентация авторских дидактических сказок студентами, учить анализировать сказки и правильно использовать в начальной школе; развивать педагогические литературные способности студентов; способствовать воспитанию 
деловых качеств будущих учителей. По желанию студенты на последней встрече зачитывали собственные сказки, давали друг другу советы, мотивировали друг друга к дальнейшей творческой деятельности. Такая встреча помогла студентам ознакомиться с опытом других, повлияла на желание в дальнейшем развивать свои литературные способности.

Кроме того, была разработана авторская дидактическая игра для создания сказок “Сказколандия». Эти карточки использовали при создании групповых дидактических сказок. Суть игры: на столе лежат пять стопок карточек (их количество можно увеличивать и уменьшать) с такими названиями: «Место расположения» (место, где происходят события сказки), «Герои» (для придумывания героев сказки), «Время», "Черты характера героев», «Необычное» (внесение нереальных фантастических элементов). Количество стопок и их содержание можно редактировать в зависимости от участников, их творчества и фантазии. Каждый участник (или один) поочередно тянет карточку и в соответствии с записанным в карточке придумывает элементы сказки. Таким образом, игра помогает быстро придумать увлекательную дидактическую сказку. Представленную авторскую игру использовали во время встреч со студентами. Участники игры были захвачены творческим процессом и утверждали, что игра очень влияет на пробуждение фантазии и творческого воображения. С помощью игры «Сказколандия» студенты создавали фрагменты сказок и групповые сказки.

Таким образом, занятия с заинтересованными студентами второго и третьего курсов имели насыщенный характер, участники получили достаточно информации в сфере создания дидактических сказок. Но, на наш взгляд, для полноценной подготовки специалистов в такой сфере необходимо большее количество часов для встреч, а также для выполнения самостоятельной работы.

Кроме этого, в мае 2017 года на базе коммунального учреждения «Седневский учебно-воспитательный комплекс (УВК)» отдела образования Черниговского района Черниговской области был проведен мастер-класс для учеников третьего класса. Спомощью авторских карточек ученики всем классом создали сказку "Оранжик и Ленивец», которая стимулировала учащихся к прилежной учебе. В следующем 2017-2018 учебном году, во время прохождения ассистентской практики, студенты 21 и 22 группы второго курса также частично ознакомились с методикой создания дидактических сказок во время лекционных 
и семинарских занятий по курсам «Педагогическое мастерство», «Методика обучения математики». На занятиях (групповая и индивидуальная работа) и при выполнении самостоятельной работы студенты создавали дидактические сказки или фрагменты сказок, часть которых вошла в сборник «Вкусные сказки».

Следующим этапом эксперимента было проведение контрольного среза, который проводился в конце мая 2017 года. Состоялось повторное анкетирование и групповой опрос с использованием расширенных и содержательных вопросов, что было включено в констатирующем эксперименте. Контрольный срез показал, что курс является эффективным и полезным для будущих учителей начальных классов. Проанализировав результаты исследования, активность и творчество студентов, мы сделали следующие замечания: а) высокий уровень подготовки к созданию сказок, в первую очередь, имеют те студенты, в которых высокий уровень мотивации и стремление самосовершенствоваться в профессиональной сфере; б) средний уровень подготовки, в основном, характеризует тех студентов, которые имеют периодический уровень мотивации развития литературных способностей, поняли методику создания дидактических сказок, но не было времени полученые знания реализовывать на практике; в) начальный уровень, в основном, характеризует студентов, прошедших курс обучения, но имеющих низкую мотивацию к применению знаний на практике. Результаты эксперимента: в 34\% студентов - высокий уровень подготовит к созданию дидактических сказок; у 55\% студентов - средний уровень и $11 \%$ - начальный.

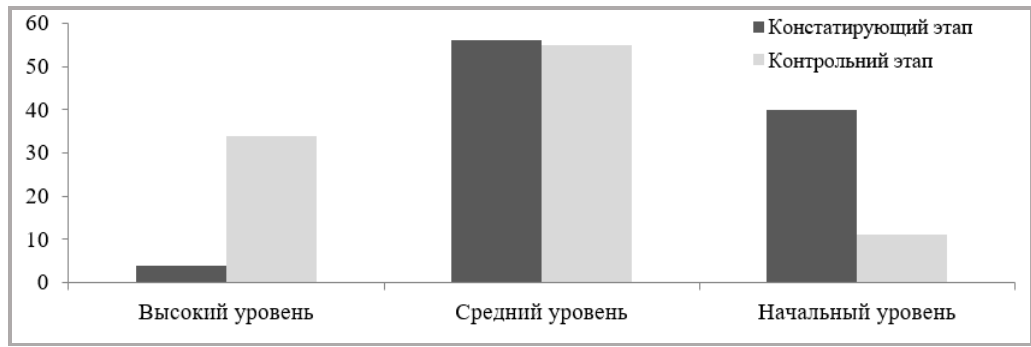

Рис. 2. Сравнительный анализ результатов констатирующего и контрольного этапов исследования 
Обработав результаты контрольного среза, получили такую дополнительную, но важную информацию: 1) большинство студентов довольны пройденным курсом, но замечают, что нужно больше семинарских занятий, чтобы лучше овладеть темой; 2) наиболее полезной для студентов была информация, касающаяся приемов и методов создания сказок; 3) после пройденного обучения большинству студентов легко и быстро составлять дидактические сказки, некоторые из них отметили, что после пройденных семинаров, они впервые в жизни составили сказку; 4) все студенты отметили, что рекомендуют другим будущим учителям начальных классов пройти такой курс обучения; 5) большинство студентов написали дидактические сказки, которые, на наш взгляд, можно использовать на уроках в начальной школе.

Наиболее ценным материалом в контрольном срезе был анализ авторских дидактических сказок, составленных студентами во время прохождения курса «Учимся составлять дидактические сказки». Анализ этих сказок дал основания утверждать: существует необходимость подготовки будущих учителей начальных классов к созданию сказок. Некоторые сказки студентов написаны на достаточно высоком уровне и могут быть рекомендованы к использованию в начальной школе. Кроме этого, произошло частичное внедрение использования дидактических сказок Черниговской общеобразовательной школе № 27. Ученики были очень заинтересованы сказками, активно взаимодействовали друг с другом и пытались даже создавать авторские групповые сказки.

Приведем пример авторской дидактической сказки «Репка», которую составила Кропта Юлия во время прохождения курса «Учимся создавать дидактические сказки». Автор отмечает, что сказку можно использовать на уроке математики в первом классе при изучении темы «Счет предметов. Название цифр и обозначение чисел цифрами» на этапе мотивации учащихся к учебной деятельности. Прорабатывая сказку, ученикам можно задавать такие вопросы: в каком порядке стояли цифры, кто посадил репку, какая цифра пришла последней? Если заблаговременно подготовить карточки Проппа, то можно дать ученикам задание расставить цифры в том порядке, в котором они стояли, когда рвали репку. При написании сказки использовала метод написания сказок Джанни Родари «Старая сказка в новом стиле». 


\section{Репка}

Жила-была себе Единичка. Сама небольшая, но очень красивая хозяйка. Раз весной взяла лопату, вскопала грядку и посадила репку. Работала единица зря: сошла репка хорошо. Ежедневно шла в огород, набрав воды полный рот, свою репку поливала, ей жизни добавляла. Росла репка, росла! Сразу такая, как мышка, была, потом, как свекла, затем, как кулак, потом, как два, а в конце стала большая и стройная.

Радуется Единичка, даже не знает, где стать. «Время, - говорит, нашу репку рвать» Пошла она в огород - хлоп-хлоп! Взяла репку за зеленые волосы: тянет руками, уперлась ногами, мучилась, потела весь день, а репка сидит в земле, как пень. Зовет Единица свою сестрицу: «Иди, Двойка, не лежи, мне репку вырвать помоги!». Пошли в огород хлоп-хлоп! Взяла Единица репку за волосы, Двойка взялась за Единицу. Тянут, аж пот течет. Промучились весь день, а репка сидит в земле, как пень. Зовет Двойка подружку: «Иди, Тройка, не лежи, нам репку вырвать помоги!». Пошли в огород - хлоп-хлоп! Взяла Единица репку за волосы, Двойка - Единицу, Тройка - Двойку. Тянут руками, упираются ногами. Промучились весь день, а репка сидит в земле, как пень. Тогда они поняли, что втроем им не справиться. Позвала Тройка свою сестрицу Четверку, Четверка - Пятерку, Пятерка - Шестёрку, Шестерка - Семерку, Семерка - Восьмерку, а Восьмерка сестрицу Девятку. И вот только когда все числа натурального ряда стали один за другим, они с легкостью вырвали репку.

Выводы и перспективы дальнейших исследований. Таким образом, проведенное исследование позволило подтвердить актуальность подготовки будущих учителей начальных классов к созданию дидактических сказок. Хорошо подготовленный учитель в теоретической сфере может создавать дидактические сказки, которые облегчают образовательный процесс учащимся, мотивируют их к обучению, побуждают к хорошим поступкам, к самосовершенствованию и тому подобное. Кроме того, на основе дидактических сказок можно создавать мультфильмы, видеоролики, которые в современном техническом мире играют важную роль в школьной жизни учеников. Подготовленный учитель может разрабатывать авторскую программу обучения по использованию дидактических сказок. 


\section{Literatura [Литература]}

Aleksanenkova M., (2013), Storymaps. Masterskaya "Yazyk SKAZKl", http://skazka1527.blogspot.com/2013_12_01_archive.html, [11.04.2019], [Алексаненкова М., (2013), StoryMaps. Мастерская "Язык СКАЗКИ", http://skazka1527.blogspot.com/2013_12_01_archive.html, [11.04.2019]].

Dichkovskaya I., (2004), Innovatsionnyye pedagogicheskiye tekhnologii uch. posobiye, Kiyev, Akademvidav, https://banauka.ru/33.html, [11.04.2019], [Дичковская И., (2004), Инновационные педагогические технологии уч. пособие, Киев, Академвидав, https://banauka.ru/33.html, [11.04.2019] ].

Ganovs'ka I., (2016), Didaktichnakazka yak pedagogichniy fenomen unavchal'no-vikhovnomu protsesi pochatkovoï shkoli, chromehttps://conference.pu.if.ua/forum/files/1113052016/1/Ganovcka.pdf, [11.04.2019], [Гановська І., (2016), Дидактична казка як педагогічний феномен у навчально-виховному прочесі початкової школи, chromehttps://conference.pu.if.ua/forum/files/1113052016/1/Ganovcka.pdf, [11.04.2019]].

HR - Portal, (2015), Metod moderatsii: Metod Uolta Disneya, https://hrportal.ru/varticle/metod-moderacii-metod-uolta-disneya, [11.04.2019], [HR - Portal, (2015), Метод модерации: Метод Уолта Диснея, https://hr-portal.ru/varticle/metod-moderacii-metod-uolta-disneya, [11.04.2019]]

Kontseptsiya «Nova ukrayins'ka shkola», (2017), http://mon.gov.ua/activity/ ... ua-sch-2016/ konczepcziya.html ...... ШкОЛИ, [11.04.2019], [Концепція «Нова українська школа», (2017), http://mon.gov.ua/activity/... ua-sch2016/ konczepcziya.html ...... ШкОлИ, [11.04.2019]].

Literaturnaya masterskaya: blog dlya nachinayushchikh pisateley, (2013), http://litmasters.ru/pisatelskoe-masterstvo, [11.04.2019], [Литературная мастерская: блог для начинающих писателей, (2013), http://litmasters.ru/pisatelskoe-masterstvo, [11.04.2019]].

Lyubavina L., (2013), Metod narezki $v$ iskusstve $i$ literature, https://textinart.wordpress.com/2013/12/19/метод-нарезки-вискусствеи-литератур/, [11.04.2019], [Любавина Л., (2013), Метод нарезки в искусстве и литературе, https://textinart.wordpress.com/ 2013/12/19/метод-нарезки-вискусстве-и-литератур/, [11.04.2019]] Mapa dumok. https://uk.wikipedia.org/wiki/Мапа_думок, [11.04.2019] [Мапа думок, https://uk.wikipedia.org/wiki/Мапа_думок, [11.04.2019]] 
Metod narizok, https://ru.wikipedia.org/wiki/Метод_нарезок, [11.04.2019], [Memod нарізок, https://ru.wikipedia.org/wiki/Метод_нарезок, [11.04.2019]].

Metodika sochinitel'stva skazok i veselykh istoriy. https://spravochnick.ru/ pedagogika/teoriya_vospitaniya/metodika_sochinitelstva_skazok_i_veselyh_istoriy /\#algoritm-sochineniya-skazok, [11.04.2019], [Методика сочинительства сказок и веселых историй, https://spravochnick.ru/pedagogika/ teoriya_vospitaniya/metodika_sochinitelstva_skazok_i_veselyh_istoriy/\#algoritm -sochineniya-skazok, [11.04.2019].

Osika O., (2011), Heshtal'T - terapiya yak faktor moral'noho rozvytku osoblyvosti shkolyara, Osvita rehionu, №3. [Осика О., (2011), Гештальт - терапія як фактор морального розвитку особливості школяра, Освіта регіону, №3].

Podari Dzh., (1990), Grammatika fantazii: vvedeniye v iskusstvo pridumyvaniya istoriy, Progres, Moskva, [Родари Дж., 1990, Грамматика франтазии: введение в искусство придумывания историй, Прогресс, Москва].

Propp V., (1986), Istoricheskiye korni volshebnoy skazki, Izdatel'stvovo Leningr. unta, Leningrad, [Пропп В., (1986), Исторические корни волшебной сказки, Издательствово Ленингр. ун-та, Ленинград].

Romanin A., Uprazhneniya $v$ geshtal'tterapii, http://www.psyarticles.ru/ view_post.php?id=216, [11.04.2019], [Романин А., Упражнения в гештальттерапии, http://www.psyarticles.ru/view_post.php?id=216, [11.04.2019]]

Strilets' S., (2015), Innovatsiyi u u vyshchiy pedahohichniy osviti: teoriya i praktyka: navch. posib. dlya studentiv vyshchykh navch, Chernihiv, Vyd., Lozovyy V.M., [Стрілець С., (2015), Інновації у вищій педагогічній освіті: теорія і практика: навч. посіб. для студентів вищих навч, Чернігів, Вид., Лозовий В.М.]

Turov M., (2003), Stvori sebe cherez kazku, v: Posib. dlya bat'kiv, uchyteliv, vykhov., keriv. hurtkiv i metod. Pid zah., (red.) S. Cherednychenko, vydavnytstvo Kobza, Kyуiv, [Туров М., (2003), Створи себе через казку, в: Посіб. для батьків, учителів, вихов., керів. гуртків і метод. Під заг., (ред.) С. Чередниченко, видавництво Кобза, Київ].

Vas vitaye sadochok Umka, (2015), Metody TRVZ - pedahohiky, http://umka2007.at.ua/blog/metodi_trvz_pedagogiki/2015-01-27-3, [11.04.2019], [Вас вітає садочок Умка, (2015), Методи ТРВ3 - педагогіки, http://umka2007.at.ua/blog/metodi_trvz_pedagogiki/2015-01-27-3, [11.04.2019]. 